\title{
A New Method for Transcarbamation and Amidation from Benzyl Carbamate
}

\author{
Gondi Sudershan Reddy ${ }^{1 *}$
}

\begin{abstract}
Affiliations:
${ }^{1}$ Departments of Chemistry, National Taiwan Normal University, Taipei, Taiwan, 116 (ROC). Correspondence email: gondisr@gmail.com
\end{abstract}

Abstracts: A convenient, and efficient method for Transcarbamation and conversion of benzyl carbamates to amide using potassium carbonate in alcohols under heating condition is described.

Keywords: Transcarbamation, Benzyl Carbamate, Amidation, Potassium carbonate, Efficient, Conversion

Introduction: Carbamate-bearing molecules play an important role in modern drug discovery and medicinal chemistry ${ }^{1}$. Carbamates are widely utilized as a peptide bond surrogate in medicinal chemistry. This is mainly due to their chemical stability and capability to permeate cell membranes. Furthermore, organic carbamates serve an especially important role as optimum protecting groups for amines and amino acids in organic synthesis and peptide chemistry $^{2}$. Transcarbamation is a process interchange of the alkoxy moiety in carbamate moiety. Transcarbamation increases number of functional group transformations reactions can possibly executed than its mono carbamate, without effecting the other functional groups, which further broaden the scope of using carbamate as protecting group ${ }^{3}$.

Benzyl carbamates are susceptible towards hydrogenation ${ }^{4}, \mathrm{HBr} / \mathrm{AcOH}^{5}, \mathrm{TMSI}^{6}$ where it requires initially cleavage, then the resulted amine need to be protected again. Transcarbamation of benzyl carbamates to alkyl carbamates is very essential. There are few 
methods $\mathrm{NaOMe}{ }^{7,8}, \mathrm{NaOH} / \mathrm{methanol} / 65^{\circ} \mathrm{C}^{9}, \mathrm{KOH} /$ water $/ 50^{\circ} \mathrm{C}^{10}$, Dibutyltin maleate ${ }^{11}$, and Tin derivatives ${ }^{12}$ were used. So, there is still to need to develop an efficient and convenient method.

Similarly, Amides, like carbamate, they also have long been used in syntheses because they offer the advantage of particularly good stability to a wide range of conditions. there are several routes for the preparation of amides. In most of this reaction, a carboxylic acid is converted into a more reactive intermediate, e.g. an acyl chloride that is then allowed to react with amine in presence of metal ${ }^{13}$ or tertiary amine ${ }^{14}$. Attempts have also been made to prepare amide directly from acid using acid activator such as dialkylphosphochloriate ${ }^{15}$, phosphorous-complex ${ }^{16}$, benzoxazole-sulfur dimer ${ }^{17}, \mathrm{EDC} / \mathrm{HOBT}^{18}$. Amides are directly prepared from alcohol ${ }^{19}$, nitrile ${ }^{20}$, oximes ${ }^{21}$, alkane ${ }^{22}$, alkyne ${ }^{23}$, boric acid ${ }^{24}$ and thioamide ${ }^{25}$. Transamidation ${ }^{26-32}$ is another way to synthesis this class of compounds, Recently conversion of carbamates ${ }^{33-37}$ to amides in single step process gaining attention because it is more advantageous than the simple amide synthesis from acid chloride and amine, due to poor solubility of some of amines in organic solvents, whereas the carbamates are commonly soluble in most of the solvents. Some carbamates, especially benzyl carbamates are readily available and thus serve conveniently as starting materials.

Present work: In continuation of work to develop new methods for functional transformation using green chemistry protocols or using easily accessible reagents, here we reporting an extremely simple but mild and convenient procedure for Transcarbamation by using Benzyl carbamate and its conversions to Amides, using potassium carbonate in alcohols under heating conditions. 
Scheme-1

$$
\begin{aligned}
& \text { A. } \mathrm{K}_{2} \mathrm{CO}_{3} / \mathrm{CH}_{3} \mathrm{OH} / \text { Reflux } \\
& \text { R-NHCOOBn } \frac{\text { B. } \mathrm{K}_{2} \mathrm{CO}_{3} / \mathrm{C}_{2} \mathrm{H}_{5} \mathrm{OH} / \text { Reflux }}{\mathrm{C} . \mathrm{K}_{2} \mathrm{CO}_{3} / \text { iso- } \mathrm{C}_{3} \mathrm{H}_{7} \mathrm{OH} / \text { Reflux/RCOCl}} \mathrm{R}-\mathrm{NHCOR}_{1} \\
& \text { R }=\text { Alkyl, Aryl, } \mathrm{R}_{1}=\mathrm{OCH}_{3}, \mathrm{OC}_{2} \mathrm{H}_{5}, \mathrm{CH}_{3}, \mathrm{C}_{2} \mathrm{H}_{5}
\end{aligned}
$$

When treated CBZ protected phthalides (1a \& 1b) in primary alcohols, methanol (Method-A) or ethanol (Method-B) using potassium carbonate, obtained transcarbamation products $\mathbf{2 a}, \mathbf{3 a}, \mathbf{2} \mathbf{b}$ and $\mathbf{3 b}$ in $\mathbf{7 5 - 8 1 \%}$ yield. Repeated same reactions in secondary alcohol, isopropyl alcohol and obtained the amide $\mathbf{4 a}$ and $\mathbf{4 b}$ respectively in $71-81 \%$ yield, by treating acid chloride with corresponding potassium salt obtained, after concentration. When these reactions are repeated in t-butyl alcohol, only recovered starting materials.

Table-1

$$
\begin{aligned}
& \text { A. } \mathrm{K}_{2} \mathrm{CO}_{3} / \mathrm{CH}_{3} \mathrm{OH} / \text { Reflux } \\
& \mathrm{R}-\mathrm{NHCOOBn} \frac{\text { B. } \mathrm{K}_{2} \mathrm{CO}_{3} / \mathrm{C}_{2} \mathrm{H}_{5} \mathrm{OH} / \text { Reflux }}{\text { C. } \mathrm{K}_{2} \mathrm{CO}_{3} / \text { iso- } \mathrm{C}_{3} \mathrm{H}_{7} \mathrm{OH} / \text { Reflux/AcCl }} \mathrm{R}-\mathrm{NHCOR}_{1}
\end{aligned}
$$

\begin{tabular}{|ccccccc|}
\hline Entry & Substrate & $\mathbf{R}$ & $\mathbf{R}_{\mathbf{1}}$ & Method & Time (h) & Yield (\%) \\
\hline 1 & 1a & 7-IsoBenzofuranyl & $\mathrm{OCH}_{3}$ & $\mathrm{~A}$ & 18 & 2a,78 \\
2 & 1a & 7-IsoBenzofuranyl & $\mathrm{OC}_{2} \mathrm{H}_{5}$ & $\mathrm{~B}$ & 18 & $3 \mathrm{a}, 76$ \\
3 & 1a & 7-IsoBenzofuranyl & $\mathrm{CH}_{3}$ & $\mathrm{C}$ & 18 & $4 \mathrm{a}, 81$ \\
4 & 1b & 4-IsoBenzofuranyl & $\mathrm{OCH}_{3}$ & $\mathrm{~A}$ & 24 & $2 \mathrm{~b}, 75$ \\
5 & 1b & 4-IsoBenzofuranyl & $\mathrm{OC}_{2} \mathrm{H}_{5}$ & $\mathrm{~B}$ & 24 & $3 \mathrm{~b}, 81$ \\
6 & 1b & 4-IsoBenzofuranyl & $\mathrm{CH}_{3}$ & $\mathrm{C}$ & 24 & $4 \mathrm{~b}, 71$ \\
7 & 1c & Cyclohexyl & $\mathrm{OCH}_{3}$ & $\mathrm{~A}$ & 18 & 2c, 80 \\
8 & 1c & Cyclohexyl & $\mathrm{OC}_{2} \mathrm{H}_{5}$ & $\mathrm{~B}$ & 18 & 3c, 82 \\
9 & 1c & Cyclohexyl & $\mathrm{CH}_{3}$ & $\mathrm{C}$ & 18 & 4c, 73 \\
\hline
\end{tabular}

Encouraged by this result, various structurally diverse benzyl carbamates (1c in table-1 and $1 \mathrm{~d}-1 \mathrm{~g}$ in table-2) have been successfully converted into their corresponding methyl, ethyl carbamates and amides in moderate to good yields. The scope of this general procedure is shown in table-2. The products from table-1 and 2 shows that chloro, methoxy, phthalide were sustained in these conditions. 
Table-2

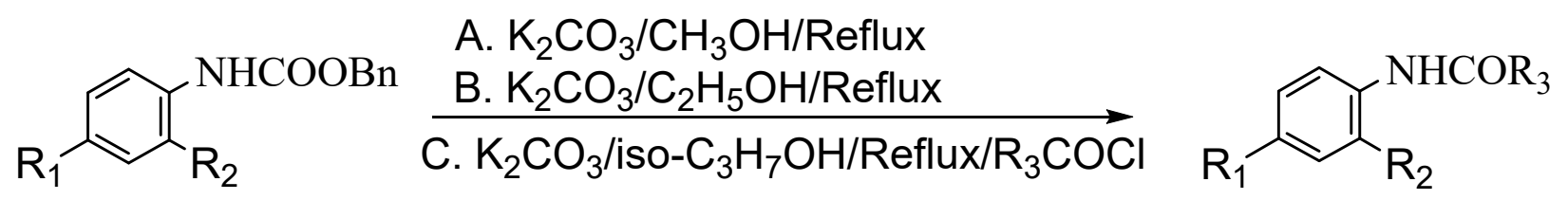

\begin{tabular}{|cccccccc|}
\hline Entry & Substrate & $\mathbf{R}_{\mathbf{1}}$ & $\mathbf{R}_{\mathbf{2}}$ & $\mathbf{R}_{\mathbf{3}}$ & Method & Time(h) & Yield (\%) \\
\hline 1 & $1 \mathrm{~d}$ & $\mathrm{Cl}$ & $\mathrm{H}$ & $\mathrm{OCH}_{3}$ & $\mathrm{~A}$ & 18 & $2 \mathrm{~d}, 85$ \\
2 & $1 \mathrm{~d}$ & $\mathrm{Cl}$ & $\mathrm{H}$ & $\mathrm{OC}_{2} \mathrm{H}_{5}$ & $\mathrm{~B}$ & 16 & $3 \mathrm{~d}, 88$ \\
3 & $1 \mathrm{~d}$ & $\mathrm{Cl}$ & $\mathrm{H}$ & $\mathrm{CH}_{3}$ & $\mathrm{C}$ & 16 & $4 \mathrm{~d}, 71$ \\
4 & $1 \mathrm{~d}$ & $\mathrm{Cl}$ & $\mathrm{H}$ & $\mathrm{C}_{2} \mathrm{H}_{5}$ & $\mathrm{C}$ & 16 & $5 \mathrm{~d}, 75$ \\
5 & $1 \mathrm{e}$ & $\mathrm{OCH}_{3}$ & $\mathrm{H}$ & $\mathrm{OCH}_{3}$ & $\mathrm{~A}$ & 16 & $2 \mathrm{e}, 80$ \\
6 & $1 \mathrm{e}$ & $\mathrm{OCH}_{3}$ & $\mathrm{H}$ & $\mathrm{OC}_{2} \mathrm{H}_{5}$ & $\mathrm{~B}$ & 16 & $3 \mathrm{e}, 83$ \\
7 & $1 \mathrm{e}$ & $\mathrm{OCH}_{3}$ & $\mathrm{H}$ & $\mathrm{CH}_{3}$ & $\mathrm{C}$ & 16 & $4 \mathrm{e}, 65$ \\
8 & $1 \mathrm{e}$ & $\mathrm{OCH}_{3}$ & $\mathrm{H}$ & $\mathrm{C}_{2} \mathrm{H}_{5}$ & $\mathrm{C}$ & 16 & $5 \mathrm{e}, 73$ \\
9 & $1 \mathrm{f}$ & $\mathrm{H}$ & $\mathrm{OCH}$ & $\mathrm{OCH}_{3}$ & $\mathrm{~A}$ & 18 & $2 \mathrm{f}, 83$ \\
10 & $1 \mathrm{f}$ & $\mathrm{H}$ & $\mathrm{OCH}$ & $\mathrm{OC}_{2} \mathrm{H}_{5}$ & $\mathrm{~B}$ & 18 & $3 \mathrm{f}, 81$ \\
11 & $1 \mathrm{f}$ & $\mathrm{H}$ & $\mathrm{OCH}$ & $\mathrm{CH}_{3}$ & $\mathrm{C}$ & 18 & $3 \mathrm{f}, 66$ \\
12 & $1 \mathrm{~g}$ & $\mathrm{H}$ & $\mathrm{H}$ & $\mathrm{OCH}_{3}$ & $\mathrm{~A}$ & 24 & $2 \mathrm{~g}, 84$ \\
13 & $1 \mathrm{~g}$ & $\mathrm{H}$ & $\mathrm{H}$ & $\mathrm{OC}_{2} \mathrm{H}_{5}$ & $\mathrm{~B}$ & 24 & $2 \mathrm{~g}, 82$ \\
14 & $1 \mathrm{~g}$ & $\mathrm{H}$ & $\mathrm{H}$ & $\mathrm{CH}_{3}$ & $\mathrm{C}$ & 16 & $2 \mathrm{~g}, 76$ \\
\hline
\end{tabular}

When dibenzyl carbamate (scheme-2) under this condition (Method-A), obtained the acid product, $2 \mathbf{i}$ where the esters group are hydrolyzed. Mild reaction condition, simplicity, ease of workup and the low toxicity and environmental impact of metal carbonates in contrast to the hazardous reagents reported in the literature are some of the noteworthy features of this methods. Though this reagent, potassium carbonate is extensively employed in organic synthesis, this new finding further broadens its versatility.

Scheme-2

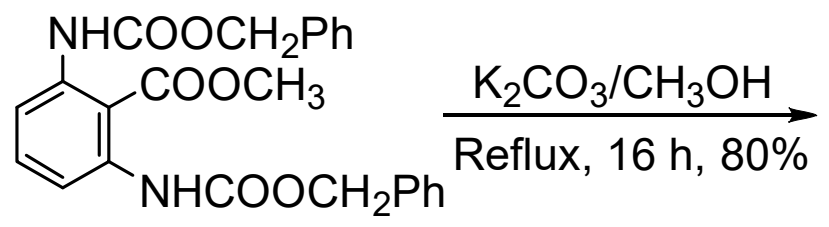<smiles>COC(=O)Nc1cccc(NC(C)=O)c1C(=O)O</smiles>

In conclusion, we have provided a new efficient as well as straight forward procedure for Transcarbamation by using benzyl carbamate in primary alcohols, and conversion of benzyl 
carbamates to amide in isopropyl alcohol by employing potassium carbonate, which is relatively inexpensive materials, involves simple workup and afforded Transcarbamation products and Amides in excellent yields.

\section{- Acknowledgement}

G.S.R thankful to National Science Council of Taiwan, (ROC) for financial support in the form of Post-Doctoral Fellowship during February 2000-July 2003. G.S.R is thankful to Chang I-Jy and Kwunmin Chen at National Taiwan Normal University, Taipei, Taiwan, for conducting the experiments and collection and processing of the spectral data are gratefully acknowledged.

- Competing interests: There is no Competing Interests pending.

\section{Reference:}

1 Ghosh, A. K. \& Brindisi, M. Organic Carbamates in Drug Design and Medicinal Chemistry. Journal of Medicinal Chemistry 58, 2895-2940, doi:10.1021/jm501371s (2015).

2 Avery, M. A. Protective Groups in Organic Synthesis. Third Edition By Theodora W. Greene and Peter G. M. Wuts. John Wiley \& Sons, New York. 1999. xxi +779 pp. $16 \times 24 \mathrm{~cm}$. ISBN 0-471-16019-9. \$84.95. Journal of Medicinal Chemistry 42, 5285-5285, doi:10.1021/jm990518h (1999).

3 Hoshi, M., Kaneko, O., Nakajima, M., Arai, S. \& Nishida, A. Total Synthesis of ( \pm )-Lundurine B. Org. Lett. 16, 768-771, doi:10.1021/o14034786 (2014).

4 Lacombe, P. et al. 3,4-Diarylpiperidines as potent renin inhibitors. Bioorganic \& Medicinal Chemistry Letters 22, 1953-1957, doi:https://doi.org/10.1016/j.bmcl.2012.01.044 (2012).

5 Geyer, A. G. et al. Preparation of naphthalenecarboximidamides as urokinase inhibitors. US6258822B1 (2001).

6 Corte, J. R., Hu, Z. \& Quan, M. L. Preparation of pyridazine derivatives as factor XIa inhibitors. WO2009114677A1 (2009).

7 Yang, Y. \& Coward, J. K. Synthesis of p-Aminophenyl Aryl H-Phosphinic Acids and Esters via Cross-Coupling Reactions: Elaboration to Phosphinic Acid Pseudopeptide Analogues of Pteroyl Glutamic Acid and Related Antifolates. The Journal of Organic Chemistry 72, 57485758, doi:10.1021/jo0707840 (2007).

8 Swayze, E. E. et al. Preparation of antibacterial 4,5-substituted aminoglycoside analogs for use as prophylactic or therapeutics against microbial infection. WO2007064954A2 (2007).

9 Parlow, J. J. et al. Synthesis and Crystal Structures of Substituted Benzenes and Benzoquinones as Tissue Factor VIIa Inhibitors. Journal of Medicinal Chemistry 46, 4297-4312, doi:10.1021/jm030233b (2003).

Ibrahim, P. N. et al. Preparation of substituted phenyl(1H-pyrrolo[2,3-b]pyridin-3yl)methanones and phenyl $(7 \mathrm{H}-$ pyrrolo[2,3-d]pyrimidin-5-yl)methanones as protein kinase modulators, particularly inhibitors of Raf protein kinases. WO2011063159A1 (2011). 
11 Ichikawa, Y. et al. An Efficient Synthesis of Carbamates by Tin-Catalyzed

Transcarbamoylation Reactions of Primary and Secondary Alcohols. Synlett 2010, 1815-1818, doi:10.1055/s-0030-1258102 (2010).

12 Bernard, J.-M., Jousseaume, B., Laporte, C. \& Toupance, T. Use of tin derivatives as catalysts for transcarbamation, carbamate compositions comprising said catalyst and method for transcarbamation. WO2002030565A1 (2002).

13 Meshram, H. M., Reddy, G. S., Muralidhar Reddy, M. \& Yadav, J. S. Zinc mediated facile amide formation: Application to alkyl, aryl, heterocycle, carbohydrate and amino acids.

Tetrahedron Letters 39, 4103-4106, doi:https://doi.org/10.1016/S0040-4039(98)00666-2 (1998).

14 Erez, R. \& Shabat, D. The azaquinone-methide elimination: comparison study of 1,6- and 1,4eliminations under physiological conditions. Organic \& Biomolecular Chemistry 6, 2669-2672, doi:10.1039/B808198K (2008).

15 Gaede, B. Preparation of Carboxamides via Carboxylic-Phosphoric Anhydrides. Organic Process Research \& Development 3, 92-93, doi:10.1021/op980205g (1999).

16 Kimura, H., Konno, H. \& Takahashi, N. A Convenient Synthesis of Amides with 2-Halo-2,3dihydro-1,3,4,2-oxadiazaphospholes as New Condensing Agents. Bulletin of the Chemical Society of Japan 66, 327-329, doi:10.1246/bcsj.66.327 (1993).

17 Ito, K., Iida, T., Fujita, T. \& Tsuji, S. A Simple Method for the Synthesis of Amides by Use of 2,2'-Dibenzothiazolyl Disulfide as an Oxidant. Synthesis 1981, 287-287, doi:10.1055/s-198129418 (1981).

18 Williams, A. \& Ibrahim, I. T. A new mechanism involving cyclic tautomers for the reaction with nucleophiles of the water-soluble peptide coupling reagent 1-ethyl-3-(3'(dimethylamino)propyl)carbodiimide (EDC). Journal of the American Chemical Society 103, 7090-7095, doi:10.1021/ja00414a011 (1981).

19 Nordstrøm, L. U., Vogt, H. \& Madsen, R. Amide Synthesis from Alcohols and Amines by the Extrusion of Dihydrogen. Journal of the American Chemical Society 130, 17672-17673, doi:10.1021/ja808129p (2008).

20 Tamaddon, F. \& Pouramini, F. Amberlyst A26 OH as a Recyclable Catalyst for Hydration of Nitriles and -Water-Based Synthesis of 4(1H)-Quinazolinones from 2-Aminobenzonitrile and Carbonyl Compounds. Synlett 25, 1127-1131, doi:10.1055/s-0033-1340986 (2014).

21 Owston, N. A., Parker, A. J. \& Williams, J. M. J. Highly Efficient Ruthenium-Catalyzed Oxime to Amide Rearrangement. Organic Letters 9, 3599-3601, doi:10.1021/o1701445n (2007).

22 Vadagaonkar, K. S., Kalmode, H. P., Prakash, S. \& Chaskar, A. C. Iodine-Mediated Domino Protocol for the Synthesis of Benz-amides from Ethylarenes via sp3 C-H Functionalization. Synlett 26, 1677-1682, doi:10.1055/s-0034-1380210 (2015).

23 Álvarez-Pérez, A., Esteruelas, M. A., Izquierdo, S., Varela, J. A. \& Saá, C. RutheniumCatalyzed Oxidative Amidation of Alkynes to Amides. Organic Letters 21, 5346-5350, doi:10.1021/acs.orglett.9b01993 (2019).

24 Huang, H. et al. Copper-Catalyzed Amidation of Arylboronic Acids with Nitriles. Synlett 27, 951-955, doi:10.1055/s-0035-1561291 (2016).

25 Inamoto, K., Shiraishi, M., Hiroya, K. \& Doi, T. Facile Conversion of Thioamides into the Corresponding Amides in the Presence of Tetrabutylammonium Bromide. Synthesis 2010, 3087-3090, doi:10.1055/s-0030-1258154 (2010).

26 Rao, S. N., Mohan, D. C. \& Adimurthy, S. 1-Proline: An Efficient Catalyst for Transamidation of Carboxamides with Amines. Organic Letters 15, 1496-1499, doi:10.1021/o14002625 (2013). 
27 Sonawane, R. B., Rasal, N. K. \& Jagtap, S. V. Nickel-(II)-Catalyzed N-Formylation and NAcylation of Amines. Organic Letters 19, 2078-2081, doi:10.1021/acs.orglett.7b00660 (2017).

28 Becerra-Figueroa, L., Ojeda-Porras, A. \& Gamba-Sanchez, D. Transamidation of Carboxamides Catalyzed by Fe(III) and Water. J. Org. Chem. 79, 4544-4552, doi:10.1021/jo500562w (2014).

29 Ghosh, T., Jana, S. \& Dash, J. KOtBu-Promoted Transition-Metal-Free Transamidation of Primary and Tertiary Amides with Amines. Organic Letters 21, 6690-6694, doi:10.1021/acs.orglett.9b02306 (2019).

30 Liu, Y., Shi, S., Achtenhagen, M., Liu, R. \& Szostak, M. Metal-Free Transamidation of Secondary Amides via Selective N-C Cleavage under Mild Conditions. Organic Letters 19, 1614-1617, doi:10.1021/acs.orglett.7b00429 (2017).

31 Krishnamurthy, M., Vishwanatha, T. M., Panguluri, N. R., Panduranga, V. \& Sureshbabu, V. V. Iodine-Mediated Oxidative Coupling of Hydroxamic Acids with Amines towards a New Peptide-Bond Formation. Synlett 26, 2565-1569, doi:10.1055/s-0035-1560266 (2015).

32 Rahman, M. M., Li, G. \& Szostak, M. Metal-Free Transamidation of Secondary Amides by NC Cleavage. The Journal of Organic Chemistry 84, 12091-12100, doi:10.1021/acs.joc.9b02013 (2019).

33 Stephenson, N. A., Gellman, S. H. \& Stahl, S. S. Ammonolysis of anilides promoted by ethylene glycol and phosphoric acid. RSC Advances 4, 46840-46843, doi:10.1039/C4RA09065A (2014).

34 Maiti, A. et al. Synthesis of Casimiroin and Optimization of Its Quinone Reductase 2 and Aromatase Inhibitory Activities. Journal of Medicinal Chemistry 52, 1873-1884, doi:10.1021/jm801335z (2009).

$35 \mathrm{Li}, \mathrm{S}$. Preparation of quaternary amine containing isobaric tags for quantitative glycan profiling. US20160252518A1 (2016).

36 Latorre, A., Rodríguez, S., Izquierdo, J. \& González, F. V. Amidation through carbamates. Tetrahedron Letters 50, 2653-2655, doi:https://doi.org/10.1016/j.tetlet.2009.03.113 (2009).

37 El Kaim, L., Grimaud, L., Lee, A., Perroux, Y. \& Tirla, C. First Carbamates Conversion to Amides by Simple Alkyl Group Transfer from Trialkylalanes. Organic Letters 6, 381-383, doi:10.1021/o1036234f(2004). 